SOSIOLIUM 2(2)(2020)

\title{
Studi Komparasi Hasil Belajar IPS dengan Menerapkan Metode Role Playing dan Metode Ceramah Bervariasi dalam Pembelajaran IPS Siswa Kelas VII SMP Negeri 2 Jakenan Kabupaten Pati
}

\author{
Lilik Yulianto, Tukidi \\ Prodi Pendidikan IPS, Fakultas Ilmu Sosial, Universitas Negeri Semarang, Indonesia.
}

\section{Info Artikel}

Sejarah Artikel:

Disubmit: Juli 2020

Direvisi: Agustus 2020

Diterima: September

2020

\section{Keywords:}

Role Playing, Lecturing

method, Learning Outcomes,

Social Science Learning

Proces

\begin{abstract}
Abstrak
Berdasarkan fakta di lapangan bahwa hasil belajar siswa menggunakan metode ceramah bervariasi dalam pembelajaran IPS belum sepenuhnya sukses. Tujuan dari penelitian ini adalah Mengetahui perbandingan hasil belajar siswa pada pembelajaran IPS antara menggunakan metode Role Playing dengan metode ceramah bervariasi kelas VII SMP Negeri 2 Jakenan Pati. Hasil penelitian menunjukkan bahwa ada perbedaan signifikan pada hasil belajar siswa kelas eksperimen dibandingkan kelas kontrol. Hasil observasi afektif kelas eksperimen berada pada rentang skor 16,58 yang berarti masuk kategori sedang dan kelas kontrol berada pada rentang skor 16,26 yang berarti masuk kategori sedang juga. Berdasarkan hasil uji-t (t-test) pada selisih skor hasil belajar pada kelas eksperimen dan kontrol diperoleh nilai t sebesar 3,249, Nilai t hitung $>t$ tabel $(3,249>$ 2,397). Kelas eksperimen memperoleh peningkatan hasil belajar rata-rata sebesar 22,76 sedangkan kelas kontrol sebesar 10,69.
\end{abstract}

\begin{abstract}
Based on the fact in the field that the students learning outcomes using a variety of lectruring methods on social science learning proces are not yet completely succes. The aim of this research is to know the students learning aoutcomes comparation between role playing method and lecturing methods on social science learning proces of first grade students of junior high school 2 Jakenan Pati. The result of this study shows that there are a significant differenciation on students learning outcomes of experimental group compared control group. The afective obeservation result is on 16,58 range score which means being in a medium category and the control group is on 16,26 range score which means in a medium category too. Based on t-test results, the deviation score between the learning outcomes on experimental group and control group is 3,249 , score of thitung $>$ ttabel $(3,249>2,397)$. The experimental group got an increasing learning outcomes range on 22,76 and 10,69 for the control group.
\end{abstract}

(C) 2020 Universitas Negeri Semarang

\footnotetext{
${ }^{\circledR}$ Alamat korespondensi:

E-ISSN 2685-4929

Gedung C1, Lantai 1, FIS Unnes

Kampus Sekaran, Gunungpati, Semarang, 50229

Email: tukidi@mail.unnes.ac.id
} 


\section{PENDAHULUAN}

Kegiatan pembelajaran merupakan kegiatan yang melibatkan beberapa komponen yaitu: siswa, guru, tujuan pembelajaran, isi pelajaran, metode pembelajaran, media pembelajaran dan evaluasi. Siswa adalah seseorang yang bertindak sebagai pencari, penerima, dan penyimpan isi pelajaran yang dibutuhkan untuk mencapai tujuan. Guru adalah seseorang yang bertindak sebagai pengelola, katalisator, dan peran lainnya yang memungkinkan berlangsungnya kegiatan belajar mengajar yang efektif. Tujuan pembelajaran adalah pernyataan tentang perubahan perilaku (kognitif, psikomotorik, afektif) yang diinginkan terjadi pada siswa setelah mengikuti kegiatan pembelajaran. Isi pelajaran adalah segala informasi berupa fakta, prinsip, dan konsep yang diperlukan untuk mencapai tujuan. Metode pembelajaran adalah cara yang teratur untuk memberikan kesempatan kepada siswa untuk mendapat informasi yang dibutuhkan mereka untuk mencapai tujuan. Media Pembelajaran adalah bahan pengajaran dengan atau tanpa peralatan yang digunakan untuk menyajikan informasi kepada siswa. Evaluasi adalah cara tertentu yang digunakan untuk menilai suatu proses dan hasilnya (Ahmad Jamroni, 2012: 01)

Metode pembelajaran adalah salah satu pendukung dimana proses pembelajaran itu menjadi bermakna. Hal ini sesuai dengan apa yang dinyatakan oleh Ashar Arsyad (2009: 15) bahwa dalam proses suatu belajar mengajar, 2 faktor yang amat penting adalah metode pembelajaran dan media pembelajaran. Lebih lanjut Uno Hamzah (2008: 2) juga mengungkapkan bahwa metode pembelajaran merupakan cara yang digunakan guru dalam menjalankan fungsinya merupakan alat untuk mencapai tujuan pembelajaran. Metode pembelajaran lebih bersifat prosedural, yaitu berisi tahapan tertentu. Metode pembelajaran menyajikan informasi atau pemahaman baru menggali pengalaman peserta belajar, menampilkan hasil unjuk kerja peserta belajar dan lain-lain.

Metode pembelajaran memegang peranan penting dalam rangkaian sistem pembelajaran, untuk itu diperlukan kecerdasan dan kemahiran guru dalam memilih metode pembelajaran. Agar tujuan belajar baik secara kognitif, afektif maupun psikomotor dapat tercapai, maka metode pembelajaraan diarahkan untuk mencapai sasaran tersebut, yaitu lebih banyak menekankan pembelajaran proses (Sumiati dan Asra, 2009: 91). Metode pembelajaran menekankan pada proses belajar siswa secara aktif dalam upaya memperoleh kemampuan hasil belajar. Proses pembelajaran yang menyenangkan merupakan salah satu faktor yang dapat menunjang keberhasilan suatu pembelajaran karena ketika pembelajaran itu dilakukan dengan cara yang menyenangkan, maka materi-materi yang dipelajari akan mudah diterima dan dimengerti oleh siswa.

Penulis ingin membandingkan penggunaan salah satu metode yang belum pernah digunakan oleh guru yaitu metode Role Playing dengan metode yang sudah digunakan oleh guru yaitu metode Ceramah Bervariasi dalam pembelajaran IPS di SMP 2 Jakenan. Peneliti melakukan observasi dan wawancara awal dengan guru mata pelajaran IPS kelas VII di SMP Negeri 2 Jakenan Kecamatan Jakenan Kabupaten Pati pada tanggal 02 Februari 2018, yaitu dengan Ambarwati, SE., berdasarkan hasil observasi dan wawancara awal beliau menyatakan sudah mencoba menerapkan beberapa variasi metode pembelajaran untuk mata pelajaran IPS. Cara yang digunakan seperti melakukan kegiatan tanya jawab pada saat memberikan materi, kadang-kadang juga diadakan diskusi atau kerja kelompok. Namun, dari pengamatan peneliti hanya sebagian saja siswa yang aktif berdiskusi sementara siswa yang lainnya bercanda atau malah diam. Siswa kurang fokus pada saat berdiskusi karena kelompok tidak terbentuk secara heterogen, siswa laki-laki mengelompok dengan sesamanya begitu pula dengan siswa perempuan. Akibatnya diskusi menjadi kurang efektif, sehingga guru cenderung lebih banyak menggunakan ceramah pada saat mengajar mata pelajaran IPS.

Permasalahan tersebut berdampak pada hasil belajar siswa kelas VII A pada mata pelajaran IPS yang masih kurang optimal. Data yang diperoleh pada saat pengamatan awal, menunjukan hasil belajar siswa masih rendah. Pada PH pertama sebnayak 20 siswa mendapat 
nilai kuran dari 70 dan hanya 9 siswa yang mendapat nilai lebih dari 70 .

Banyak metode pembelajaran yang dapat digunakan dalam pembelajaran IPS untuk menjadikan siswa menjadi aktif dalam kegiatan belajar mengajar. Salah satunya adalah metode Role Playing atau bermain peran dikatakan sama dengan metode sosiodrama sehingga dalam penggunaannya sering disiligantikan (Syaiful Bahri Djamarah dan Aswan Zein, 2006: 87). Roestiyah N.K (2001: 90) menyatakan dengan metode Role Playing siswa berperan atau mendramatisasi tingkah laku dalam hubungannya dengan masalah sosial, sedangkan pada sosiodrama siswa dapat mendramatisi tingkah laku, gerak-gerik seseorang dalam hubungannya dengan sesama manusia. Role Playing atau bermain peran merupakan metode pembelajaran yang bertujuan menggambarkan masa lampau, atau dapat pula bercerita tentang berbagai kemungkinan yang terjadi baik kini atau mendatang (Sumiati dan Asra, 2009: 99).

Metode Role Playing dapat dijadikan sebagai salah satu variasi metode yang dapat digunakan untuk mengajarkan siswa SMP kelas VII semester II. Metode Role Playing ini belum pernah dicoba oleh guru pengampu mata pelajaran IPS dalam pembelajaran IPS di kelas VII A SMP Negeri 2 Jakenan. Oleh karena itu, peneliti tertarik untuk menerapkan pembelajaran IPS dengan menggunakan metode Role Playing dalam pembelajaran IPS di Kelas VII A SMP Negeri 2 Jakenan Kabupaten Pati dan membandingannya dengan metode Ceramah Bervariasi. Diharapkan dengan menerapkan metode Role Playing, siswa menjadi lebih aktif dalam kegiatan belajar dan hasil belajarnya semakin meningkat.

Berdasarkan latar belakang yang telah dijelaskan, maka penulis merumuskan masalah sebagai berikut: (1) Bagaimana hasil belajar siswa pada pembelajaran IPS menggunakan metode Role Playing kelas VII SMP Negeri 2 Jakenan Kabupaten Pati? (2) Bagaimana hasil belajar siswa pada pembelajaran IPS menggunakan metode ceramah bervariasi kelas VII SMP Negeri 2 Jakenan Kabupaten Pati? (3) Adakah perbandingan hasil belajar siswa pada pembelajaran IPS antara menggunakan metode
Role Playing dengan metode ceramah bervariasi kelas VII SMP Negeri 2 Jakenan Kabupaten Pati?

Berdasarkan permasalahan yang telah dirumuskan, maka tujuan dari penelitian ini adalah: (1) Mengetahui hasil belajar siswa pada pembelajaran IPS menggunakan metode Role Playing kelas VII SMP Negeri 2 Jakenan Kabupaten Pati. (2) Mengetahui hasil belajar siswa pada pembelajaran IPS menggunakan metode ceramah bervariasi kelas VII SMP Negeri 2 Jakenan Kabupaten Pati. (3) Mengetahui adakah perbandingan hasil belajar siswa pada pembelajaran IPS antara menggunakan metode Role Playing dengan metode ceramah bervariasi kelas VII SMP Negeri 2 Jakenan Kabupaten Pati.

\section{METODE PENELITIAN}

Pendekatan yang digunakan dalam penelitian ini adalah pendekatan kuantitatif. Pendekatan kuantitatif berlandasakan pada filsafat positivisme, biasa digunakan untuk meneliti populasi atau sampel tertentu dengan menggunakan instrumen penelitian. Data penelitian yang digunakan berupa angka-angka serta analisis, sehingga disebut dengan metode kuantitatif. Analisis data bersifat kuantitatif/statistik dengan tujuan menguji hipotesis yang sudah ditetapkan sebelumnya (Sugiyono, 2010: 14).

Jenis penelitian yang digunakan adalah eksperimen, penelitian ini menguji secara langsung pengaruh suatu variabel terhadap variabel lain serta menguji hipotesis hubungan sebab-akibat (Nana Syaodih Sukmadinata, 2010: 194). Peneliti memilih jenis penelitian eksperimen dengan tujuan untuk meneliti ada tidaknya hubungan sebab akibat dari sesuatu yang dikenakan kepada objek yang diteliti. Caranya adalah membandingkan kelas yang mendapatkan perlakuan khusus dan kelas yang tidak mendapatkan perlakuan.

Ada beberapa desain penelitian eksperimen, dalam penelitian ini digunakan Quasi Experimental Design (Sugiyono, 2010: 114). Bentuk desain eksperimen kuasi ini bukan eksperimen murni, tetapi seolah-olah murni. Eksperimen ini juga dapat dikatakan sebagai eksperimen semu karenavberbagai hal terutama dalam pengontrolan variabel yang sukar pada eksperimen murni (Nana Syaodih Sukmadinata, 
2010: 207). Desain ini memiliki kelas kontrol, tetapi tidak dapat berfungsi sepenuhnya untuk mengontrol variabel-variabel luar yang mempengaruhi pelaksanaan eksperimen. Dalam Quasi Experimental Design terdapat dua bentuk desain quasi eksperimen, yaitu Time-Series Design dan Nonequivalent Control Group Design (Sugiyono, 2010: 114).

Desain yang digunakan dalam penelitian ini adalah Nonequivalent Control Group Design (Sugiyono, 2010:116), pada desain eksperimen ini terdapat kelas eksperimen dan kelas kontrol sebagai pembanding. Pada penelitian ini, peneliti memberi perlakuan khusus menggunakan metode Role Playing dalam pembelajaran IPS pada kelas eksperimen. Sedangkan pada kelas kontrol tidak diberi perlakuan khusus.

Menurut Sugiyono (2014: 119), "populasi adalah wilayah generalisasi yang terdiri atas: objek/subjek yang mempunyai kualitas dan karakteristik tertentu yang ditetapkan oleh peneliti untuk dipelajari dan kemudian ditarik kesimpulannya". Arikunto (2010: 173), mendefinisikan bahwa "populasi adalah keseluruhan objek penelitian". Pendapat lain dari Sanjaya (2013: 228), menyebutkan bahwa populasi adalah keseluruhan yang menjadi target dalam menggeneralisasikan hasil penelitian. Dalam penelitian ini yang menjadi populasi adalah siswa kelas VII A-E SMP Negeri 2 Jakenan Kabupaten Pati yang berjumlah 146 orang siswa dari 5 kelas.

Sugiyono (2014: 120), mengemukakan bahwa sampel adalah bagian dari jumlah dan karakteristik yang dimiliki oleh populasi tersebut. Sementara, menurut Arikunto (2010:174), "sampel adalah sebagian atau wakil populasi yang diteliti". Jadi, sampel adalah sebagian dari keseluruhan populasi yang diteliti.

Menurut Sugiyono (2014: 121), teknik sampling adalah teknik pengambilan sampel. Sependapat dengan Sukmadinata (2012: 252), yang menyebutkanpengambilan sampel merupakan suatu proses pemilihan dan penentuan jenis sampel dan perhitungan besarnya sampel yang akan menjadi subjek atau objek penelitian". Untuk menentukan sampel yang akan digunakan dalam penelitian, terdapat berbagai teknik sampling yang digunakan. Teknik sampling pada dasarnya dikelompokkan menjadi dua yaitu: (1) probability sampling, yaitu teknik pengambilan sampel dimana memberikankesempatan yang sama bagi setiap anggota populasi untuk dipilih menjadi anggota sampel. Teknik ini meliputi: simple random sampling, proportionatestratified random sampling, disproportionate stratified random sampling, serta area sampling; (2) non-probability sampling, yaitu teknik pengambilan sampeldimana tidak memberikan kesempatan yang sama bagi setiap anggota populasi untuk dipilih menjadi sampel. Teknik sampel ini meliputi: sampling sistematis, sampling kuota, sampling aksidental, purposive sampling, sampling jenuh, serta snowball sampling (Sugiyono, 2014: 121-5).

Dalam penelitian ini, penentuan jumlah sampel menggunakan purposive sampling yaitu teknik penentuan sampel dengan pertimbangan tertentu. Purposive sampling digunakan apabila sasaran sampel yang diteliti telah memiliki karakteristik tertentu sehingga tidak mungkin diambil sampel yang lain yang tidak memenuhi karakteristik yang ditetapkan. Pertimbangan penentuan sampel yang memiliki karakteristik dan kemampuan akademik relative sama. Dalam hal ini, guru yang mengajar kelas tersebut merekomendasi yaitu, kelas VII A sebagai kelas ekperimen, dan VII C sebagai kelas control.

Variabel penelitian adalah suatu atribut, sifat, nilai dari orang, obyek atau kegiatan yang mempunyai variasi tertentu yang ditetapkan oleh peneliti untuk dipelajari kemudian ditarik kesimpulannya (Sugiyono, 2010: 61). Dalam hubungannya variabel dibedakan menjadi variabel Independen atau variabel bebas, dan variabel dependen atau variabel terikat.

Variabel bebas merupakan variabel yang mempengaruhi atau menjadi sebab timbulnya variabel terikat, sedangkan variabel terikat adalah variabel yang dipengaruhi atau menjadi akibat. Variabel bebas dalam penelitian ini adalah metode Role Playing dan metode ceramah bervariasi sedangkan variabel terikatnya adalah hasil belajar IPS.

Teknik pengumpulan data yang digunakan dalam penelitian ini adalah tes hasil belajar dan observasi masing-masing akan dijelaskan lebih detail sebagai berikut Suharsimi Arikunto (2010: 266) menyatakan bahwa tes untuk manusia adalah instrumen yang digunakan 
untuk mengukur kemampuan dasar atau prestasi. Zainal Arifin (2012: 118) menambahkan, bahwa tes merupakan suatu teknik atau cara yang digunakan dalam rangka pengukuran, didalamnya terdapat pertanyaan yang harus dikerjakan siswa untuk mengukur kemampuannya. Penelitian ini menggunakan tes berupa pilihan ganda dengan 4 pilihan jawaban untuk mengetahui hasil belajar IPS siswa kelas VII sebelum dan sesudah diberikan perlakuan.

Observasi merupakan sebuah proses pengamatan dan pencatatan secara sistematis, logis, objektif, dan rasional mengenai berbagai fenomena, dalam situasi yang sebenarnya atau dalam situasi buatan untuk mencapai tujuan tertentu (Zainal Arifin, 2012: 153). Dalam pembelajaran, observasi dapat digunakan untuk menilai proses dan hasil belajar siswa. Seperti tingkah laku siswa pada saat belajar, berdiskusi, melaksanakan tugas dan sebagainya.

Teknik analisis data yang digunakan pada penelitian ini yaitu, analisis deskriptif, kriteria kategori skor dan uji prasyarat yang terdiri dari uji normalitas, uji homogenitas dan uji t-test.

\section{HASIL PENELITIAN}

Penelitian ini diadakan untuk mengetahui pengaruh metode Role Playing terhadap hasil belajar IPS siswa kelas VII A SMP Negeri 2 Jakenan, tahun ajaran 2017/ 2018. Penelitian dilaksanakan pada bulan September dengan 3 kali pertemuan dengan kompetensi inti, kompetensi dasar serta materi yang sama. Dalam pelaksanaannya, terlebih dahulu diadakan pre test untuk mengetahui kondisi awal siswa setara atau tidak. Kemudian selama proses pembelajaran dilakukan observasi sikap siswa. Pada akhir penelitian atau setelah materi diajarkan diadakan post test untuk mengetahui hasil belajar siswa. Deskripsi tentang pemberian perlakuan akan dijabarkan sebagaimana berikut:

\section{Pemberian Perlakuan Pada Kelas Eksperimen \\ a. Pemberian Pre Test}

Pelaksanaan pada kelas eksperimen diawali dengan pemberian pre test pada rabu, 8 agustus 2018, siswa mengerjakan pre test yang berupa pilihan ganda sebanyak 20 soal. Setelah pre test diberikan, kelas ekserimen siswa diberi tahu bahwa pada pertemuan berikutnya pembelajaran IPS akan menggunakan metode Role Playing. Selanjutnya peneliti membentuk 4 kelompok berdasarkan berhitung dan perwakilan anggota kelompok mengambil undian teori mana nanti yang akan diperankan oleh kelompok tersebut. Kelompok yang akan memerankan pada pertemuan pertama pada kelas eksperimen adalah kelompok yang mendapat teori waisya dan teori ksatria. Masing-masing kelompok membagi tugas anggotanya ada yang bertugas sebagai tokoh, narator dan notulen. Siswa yang nantinya berperan mendapatkan naskah drama untuk dipelajari di rumah.

\section{b. Pertemuan Pertama}

Pertemuan pertama dilaksanakan pada selasa, 28 agustus 2018. Beberapa siswa (sejumlah siswa dari dua kelompok) mendapat giliran maju pertama untuk memainkan drama. Siswa yang bermain peran pada pertemuan pertama adalah kelompok yang mendapatkan teori waisya dan teori ksatria. Pelaksanaan pembelajaran pada pertemuan pertama sesuai dengan rencana pelaksanaan pembelajaran (RPP) yang disusun oleh peneliti. Materi yang digunakan pada pertemuan pertama adalah teori waisya dan teori ksatria.

Pelaksanaan pembelajaran pada pertemuan pertama dimulai dengan kegiatan awal, Guru mengawali pembelajaran dengan apersepsi, dilanjutkan dengan tanya jawab berkaitan dengan materi. Siswa yang sebelumnya ditunjuk untuk memerankan drama mempersiapkan diri. Sementara siswa pemeran drama mempersiapkan diri, guru membagi kelompok pada siswa yang bertugas sebagai pengamat. Selanjutnya kegiatan inti, siswa yang mendapatkan peran memainkan drama peristiwa masuknya Hindu-Budha ke Indonesia yaitu teori waisya dan kesatria (latihan), sementara siswa yang bertugas sebagai pengamat mengamati sambil mengerjakan Lembar Kerja Siswa yang telah disediakan bersama kelompoknya. Selama siswa memainkan peran guru mengawasi dan memberikan dorongan serta motivasi. Setelah permainan selesai diadakan diskusi mengenai jalannya Role Playing dilanjutkan dengan pembahasan materi yang telah dimainkan. Kemudian guru memberikan tindak lanjut 
berupa evaluasi individu. Setelah evaluasi selesai, siswa dengan bimbingan guru menyimpulkan materi yang telah dipelajari. Di akhir pembelajaran, guru mengingatkan dua kelompok yang maju pada pertemuan selanjutnya agar lebih dipersiapkan dengan baik.

\section{c. Pertemuan Kedua}

Pertemuan kedua dilaksanakan pada rabu, 29 agustus 2018. Pada pertemuan pertama, dua kelompok telah memainkan drama (Role Playing). Dua kelompok selanjutnya bermain peran pada pertemuan kedua ini. Pelaksanaan pembelajaran pada pertemuan kedua sesuai dengan rencana pelaksanaan pembelajaran (RPP) yang disusun oleh peneliti. Materi yang digunakan pada pertemuan kedua adalah teori brahmana dan teori arus balik tetang masuknya Hindu-Budha di Indonesia.

Pelaksanaan pembelajaran pada pertemuan kedua dimulai dengan kegiatan awal, guru mengawali pembelajaran dengan apersepsi. kelompok yang akan maju memerankan drama diminta mempersiapkan diri. Peneliti menyuruh dua kelompok yang sebelumnya telah maju bertugas sebagai pengamat. Selanjutnya kegiatan inti, masing masing kelompok maju bergantian memainkan drama teori brahmana dan dilanjut teori arus balik, sementara kelompok yang lain bertugas sebagai pengamat mengamati bersama dengan kelompoknya. Setelah permainan selesai, guru mengadakan diskusi disertai tanya jawab mengenai jalannya Role Playing dilanjutkan dengan pembahasan materi yang telah dimainkan. Kemudian guru memberikan tindak lanjut berupa evaluasi individu. Setelah evaluasi siswa dengan bimbingan guru menyimpulkan materi yang telah dipelajari. Di akhir pembelajaran, guru membagikan naskah drama kepada beberapa siswa yang mau menjadi sukarelawan untuk memainkan peran pada pertemuan selanjutnya sejumlah 6 orang siswa yang satu narator.

\section{d. Pertemuan Ketiga}

Pertemuan ketiga dilaksanakan pada selasa, 4 september 2018. Pelaksanaan pembelajaran pada pertemuan ketiga tidak sesuai dengan rencana pelaksanaan pembelajaran (RPP) yang disusun oleh peneliti. Dikarenakan waktu mepet dengan pelaksanaan PTS, proses pembelajaran dilaksanakan diluar jam pelajaran.
Materi yang digunakan pada pertemuan ketiga adalah masuknya Hindu-Budha teori Brahmana dikarenakan pada pertemuan pertama hasilnya kurang maksimal dan pengulasan kembali ke empat teori masuknya Hindu-Budha.

Pelaksanaan pembelajaran pada pertemuan ketiga dimulai dengan kegiatan awal, guru mengawali pembelajaran dengan apersepsi berupa tanya jawab. Selanjutnya kegiatan inti, siswa yang mendapatkan peran memainkan drama menampilkan teori masuknya Hindu Budha teori waisya dan ksatria, sementara siswa pengamat mengamati sambil mengerjakan Lembar Kerja Siswa yang telah disediakan. Setelah permainan drama selesai, guru mengadakan diskusi disertai tanya jawab mengenai jalannya Role Playing dilanjutkan dengan pembahasan materi yang telah dimainkan. Kemudian guru memberikan tindak lanjut berupa evaluasi individu. Setelah evaluasi siswa dengan bimbingan guru menyimpulkan materi yang telah dipelajari.

\section{e. Pemberian Post Test}

Pemberian post test untuk kelas eksperimen dilaksanakan pada rabu, 5 september 2018. Soal yang diberikan berupa pilihan ganda sebanyak 20 buah. Post test ini dilakukan beberapa saat setelah pemberian perlakuan untuk mengetahui hasil belajar IPS.

\section{Pemberian Perlakuan Pada Kelas Kontrol \\ a. Pemberian Pre Test \\ Pemberian pre test pada kelas kontrol} dilaksanakan pada jum'at, 10 agustus 2018. Siswa kelas kontrol mengerjakan soal pilihan ganda yang sama seperti pada kelas eksperimen.

\section{b. Pertemuan Pertama}

Pembelajaran pada pertemuan pertama dilaksanakan pada hari rabu, 29 agustus 2018 . Materi yang diberikan pada kelas kontrol merupakan materi yang sama dengan kelas eksperimen, yaitu masuknya Hindu-Budha di Indonesia teori waisya dan ksatria. Pembelajaran diawali dengan kegiatan awal, dilanjutkan kegiatan inti dan kegiatan akhir.

Kegiatan awal meliputi apersepsi, mempersiapkan kondisi kelas dan kelengkapan belajar, serta kegiatan tanya jawab. Selanjutnya kegiatan inti guru bercerita mengenai masuknya Hindu-Budha di Indonesia teori waisya dan 
ksatria. Siswa diminta menyimak materi dari buku pelajaran. Selanjutnya siswa berdiskusi terkait materi yang diberikan dengan teman sebangku. Kemudian siswa diberikan soal evaluasi individu sebagai tindak lanjut. Siswa yang ingin bertanya terkait materi yang belum dipahami diberikan kesempatan bertanya. Kegiatan pembelajaran diakhiri dengan pesan moral dan motivasi agar siswa giat belajar.

\section{a. Pertemuan Kedua}

Pembelajaran pada pertemuan kedua dilaksanakan pada hari jum'at, 31 agustus 2018. Materi yang diberikan pada kelas kontrol pada pertemuan kedua merupakan materi yang sama dengan kelas eksperimen, yaitu masuknya Hindu-Budha di Indonesia teori Brahmana dan arus balik. Pembelajaran diawali dengan kegiatan awal, dilanjutkan kegiatan inti dan kegiatan akhir.

Kegiatan awal meliputi apersepsi, mempersiapkan kondisi kelas dan kelengkapan belajar, serta kegiatan tanya jawab. Selanjutnya kegiatan inti guru bercerita mengenai masuknya Hindu-Budha di Indonesia teori Brahmana dan arus balik. Siswa diminta menyimak materi dari buku pelajaran. Selanjutnya siswa membuat catatan terkait dengan materi yang disampaikan oleh guru. Kemudian siswa diberikan soal evaluasi individu sebagai tindak lanjut. Siswa yang ingin bertanya terkait materi yang belum dipahami diberikan kesempatan bertanya. Kegiatan pembelajaran diakhiri dengan pesan moral dan motivasi agar siswa giat belajar.

\section{c. Pertemuan Ketiga}

Pembelajaran pada pertemuan kedua dilaksanakan pada hari rabu, 5 september 2018. Materi yang diberikan pada kelas kontrol merupakan materi yang sama dengan kelas eksperimen, yaitu mengulas kembali ke empat teori masuknya Hindu-Budha di Indonesia. Pembelajaran diawali dengan kegiatan awal, dilanjutkan kegiatan inti dan kegiatan akhir.

Kegiatan awal meliputi apersepsi, mempersiapkan kondisi kelas dan kelengkapan belajar, serta kegiatan tanya jawab. Selanjutnya kegiatan inti guru bercerita mengenai berbagai upaya. Siswa diminta menyimak materi dari buku pelajaran dan presentasi keempat kelompok yang sudah maju pada pertemuan sebelumnya. Kemudian siswa diberikan soal evaluasi individu sebagai tindak lanjut. Siswa yang ingin bertanya terkait materi yang belum dipahami diberikan kesempatan bertanya. Kegiatan pembelajaran diakhiri dengan pesan moral dan motivasi agar siswa giat belajar.

\section{d. Pemberian Post Test}

Pemberian post test untuk kelas kontrol dilaksanakan pada jum'at, 7 september 2018. Soal yang diberikan sama seperti yang diberikan pada kelas eksperimen berupa pilihan ganda sebanyak 20 buah.

Berdasarkan data yang diperoleh, setelah penelitian dilaksanakan. Diperoleh data peningkatan hasil belajar ranah kognitif yang kemudian dianalisis dengan uji-t (t-test). Hasil pre test kelas eksperimen yang menggunakan metode Role Playing mendapatkan nilai rata-rata hasil tes awal 38,6 dan kelas Kontrol yang mendapatkan perlakuan sewajarnya atau metode ceramah bervariasi mendapatkan nilai rata-rata hasil tes awal 41,5.

Hasil analisis data dengan uji-t (t-test) pada post test atau tes akhir menunjukkan ada perbedaan yang signifikan antara nilai kelas eksperimen yang telah diajar dengan metode Role Playing dengan kelas kontrol yang diajar dengan metode ceramah bervariasi. Hal tersebut diperkuat dengan nilai rata-rata yang jauh berbeda. Kelas eksperimen mendapatkan nilai rata-rata sebesar 61,4 sedangkan kelas kontrol mendapatkan nilai rata-rata sebesar 52,2. Dengan demikian dapat dinyatakan bahwa ada perbedaan hasil yang signifikan antara kelas eksperimen dan kelas kontrol.

Hasil analisis data dengan uji-t (t-test) pada selisih hasil belajar siswa kelas eksperimen dan kelas kontrol juga memperkuat perbedaan secara signifikan pada hasil belajar kedua kelas. Hasil Pre Test dan Post Test menunjukkan ada peningkatan pada kelas eksperimen sebesar 22,75862 . Sedangkan peningkatan yang terjadi pada kelas kontrol sebesar 10,68966. Peningkatan yang lebih besar pada siswa kelas eksperimen yang diajar dengan metode Role Playing menunjukkan bahwa metode ini memiliki pengaruh terhadap hasil belajar siswa kelas VII SMP Negeri 2 Jakenan.

Berdasarkan data yang diperoleh dari observasi sikap siswa pada kelas eksperimen menunjukkan nilai rata-rata pertemuan I adalah 
15,79 yang berarti masuk pada kategori sedang, pertemuan II sebesar 16,83 masuk pada kategori sedang, dan pertemuan III sebesar 17,72 yang berarti masuk ke dalam kategori sedang. Dari ketiga pertemuan tersebut menunjukkan bahwa rata-rata nilai sikap siswa berada pada kategori tinggi. Sedangkan pada kelas kontrol, sikap siswa berada pada kategori rendah pada setiap pertemuan. Pertemuan I nilai rata-rata sikap siswa kelas eksperimen sebesar 15,83, kemudian pertemuan II sebesar 16,24 dan pertemuan III sebesar 16,72. Apabila sikap siswa dari ketiga pertemuan dirata-rata, maka pada kelas eksperimen rata-ratanya adalah 16,58 yang berarti pada kategori sedang, sedangkan kelas kontrol rata-ratanya adalah 15,26 yang berarti berada pada kategori sedang juga. Hal ini dikarenakan perlakuan dari guru atau metode pembelajaran yang diberikan kepada setiap kelas berbeda.

Pembelajaran yang diterima kelas kontrol merupakan pembelajaran yang biasa dilakukan guru yaitu dengan ceramah bervariasi. Hasil pengamatan pada siswa kelas kontrol menunjukkan bahwa siswa kurang antusias dalam mengikuti proses pembelajaran. Guru memang lebih mudah dalam mengkondisikan siswa untuk memperhatikan materi yang dibawakan, namun perhatian siswa terhadap materi hanya terjadi pada menit-menit awal pada proses pembelajaran. Selanjutnya perhatian siswa terhadap pembelajaran berkurang.

Sedangkan Pembelajaran pada kelas eksperimen menggunakan metode Role Playing atau bermain peran. Metode Role Playing dalam pelaksanaanya dilakukan dengan berperan atau memainkan peranan dalam dramatisasi masalah sosial. Sebagaimana yang disampaikan Hamzah B. Uno (2010: 90) bahwa metode Role Playing atau bermain peran membantu siswa menemukan jati diri di dunia sosial dan memecahkan dilema atau permasalahan yang dihadapi. Metode ini menarik bagi siswa karena proses pembelajaran dilakukan seperti sebuah permainan. Role playing sebagaimana yang disampaikan oleh Syaiful B. Djamarah dan Aswan (2006:89) Role Playing dapat menjadikan siswa lebih memahami isi bahan yang didramakan, dalam penelitian ini isi dari bahan yang didramakan adalah teori masuknya Hindu-
Budha di Indonesia. Siswa kelas eksperimen lebih memahami isi dari bahan yang diajarkan karena siswa memerankan tokoh yang terlibat dalam peristiwa yang terjadi. Sehingga hasil belajar IPS siswa kelas eksperimen menjadi lebih baik karena metode Role Playing menjadikan siswa lebih aktif dan memberikan pengalaman yang berkesan bagi siswa. Hal tersebut menunjukkan bahwa ada perbandingan hasil belajar IPS menggunakan metode Role Playing dan menggunakan metode ceramah bervariasi pada siswa kelas VII SMP Negeri 2 Jakenan.

\section{SIMPULAN DAN SARAN}

\section{Simpulan}

Hasil belajar IPS siswa kela eksperimen pada domain afektif dan psikomotorik skornya adalah 17,34 pada domain kognitif mendapat peningkatan rata-rata 22,76 sedangkan hasil belajar IPS kelas kontrol sebesar 16,94 pada domain afektif dan psikomotorik 10,69. Hasil penghitungan uji-t (t-test) pada peningkatan nilai rata-rata menyatakan bahwa nilai t hitung sebesar 3,249 . Nilai t hitung $>t$ tabel $(3,249>2,397)$. Hal ini menunjukkan ada pengaruh secara signifikan dari perbedaan perlakuan yang diterima pada kedua kelas.

Dapat disimpulkan bahwa metode Role Playing memberikan pengaruh terhadap hasil belajar IPS siswa kelas VII SMP Negeri 2 Jakenan. Metode Role Playing pada kelas eksperimen lebih efektif dalam peningkatan perolehan hasil belajar dibandingkan dengan pembelajaran dengan metode ceramah bervariasi pada kelas kontrol.

\section{Saran}

Berdasarkan pada kesimpulan yang telah disampaikan, maka peneliti mengajukan saran sebagaimana berikut: Metode Role Playing bisa menjadi alternatif pilihan bagi guru untuk diterapkan dalam pembelajaran dikelas dikarenakan siswa menjadi lebih aktif dalam kegiatan belajar dan hasil belajarnya semakin meningkat. Hal tersebut bisa dilihat dari hasil penelitian metode Role Playing pada kelas eksperimen lebih efektif dalam peningkatan perolehan hasil belajar dibandingkan dengan pembelajaran dengan metode ceramah bervariasi pada kelas kontrol. 


\section{DAFTAR PUSTAKA}

Arifin, Zainal. 2012. Evaluasi Pembelajaran. Bandung: Remaja Rosdakarya Azhar Arsyad. 2009. Media Pembelajaran. Jakarta: Penerbit Rajawali

Hamzah B. Uno. 2010. Model Pembelajaran Menciptakan Proses Belajar Mengajar yang Kreatif dan Efektif. Jakarta: Bumi Aksara. 2008. ModelPembelajaran. Jakarta: BumiAksara

Jamroni, Ahmad. 2012. Perbandingan pembelajaran sejarah menggunakan media wikipedia dan menggunakan media buku $L K S$ dalam materi revolusi industri terhadap hasil belajar siswa kelas XI IPS di SMA Negeri 1 Jakenan Kabupaten Pati. Semarang: Universitas Negeri semarang.
Roestiyah N.K. 2001. Strategi Belajar Mengajar. Jakarta: Rineka Cipta.

Sugiyono. 2010. Metode Penelitian Pendidikan Pendekatan Kuantitatif, Kualitatif, dan $R \& D$. Bandung: Alfabeta.

2014.Metode Penelitian Kuantitatif, Kualitatif, dan $R \& D$. Bandung: Alfabeta.

Suharsimi Arikunto. 2010. Prosedur Penelitian Suatu Pendekatan Praktik. Jakarta: Rineka Cipta.

Sukmadinata, Nana Syaodih. (2010). Metode Penelitian Pendidikan. Bandung: PT.

Sumiati \&Asra. 2009. Metode Pembelajaran. Bandung: CV Wacana Prima.

Syaiful Bahri Djamarah \& Aswan Zain. 2006. Strategi Belajar Mengajar. Bandung: Rineka Cipta.

Sukmadinata. (2010). Metode Penelitian Pendidikan. Bandung: PT. 